\title{
MIHKEL VESKE PANUSEST VENE KEELDE LAENATUD SOOME-UGRI SÕNADE UURIMISSE
}

\author{
ENN ERNITS
}

\begin{abstract}
Annotatsioon. Kirjutises analüüsitakse Mihkel Veske keelekontakte käsitleva monograafia (Veske 1890) esimest peatükki, milles autor vaatleb soome-ugri keeltest laenatud sõnu vene murretes. Kõigepealt antakse artiklis lühiülevaade seesuguste laensõnade uurimise ajaloost XIX sajandil ning M. Veske monograafiast kui tervikust ja senistest hinnangutest selle kohta. Kirjutise põhiosas üritatakse hinnata M. Veske panust laensõnade uurimisse õigete, poolenisti õigete ja valede etümoloogiate eristamise ja nende protsentuaalse osatähtsuse kindlakstegemisega. M. Veske on käsitlenud ühtekokku 105 vene murdesõna, mis tema andmetel on laenatud soome-ugri keeltest. Neist on ta 21 sõna uurinud esimesena. Enamik monograafias vaadeldud vene sõnu on laenatud läänemeresoome keeltest. Peale nende leidub õige etümoloogiaga laensõnade hulgas vaid neli komi päritolu vene lekseemi. Kirjutises hinnatakse vene üldsõnade laenusuundade ja etümoloogiate õigsust M. Veske antud tähendusrühmade kaupa. Kalanduse ja veesõiduga ning esemete ja materjalidega seotud laensõnadest osutusid õigeks ainult pooled. Kõige õigemini oli M. Veske käsitlenud loodusega seotud laensõnu, nende hulgas leidub tänini käibivaid etümoloogiaid ligikaudu 68\%. Tähenduselt liigitamata rühm, milles on õigeid etümoloogiaid $43 \%$, sisaldab erinevalt eelmistest rühmadest peamiselt tegusõnu. Kokkuvõtlikult võib nentida, et M. Veske on oma monograafias õigesti etümologiseerinud üle poole enda käsitletud laensõnadest.
\end{abstract}

Võtmesõnad: Mihkel Veske, keeleuurimise ajalugu, läänemeresoome keeled, leksikoloogia, keelekontaktid, võrdlev-ajalooline uurimismeetod

\section{Sissejuhatuseks}

Kirjutis on mõtteliseks järjeks käesolevate ridade autori varasematele keeleajaloolistele artiklitele Mihkel Veske tegevuse kohta (vt Ernits 2008, 2009, 2010). Artikkel käsitleb XIX sajandi keele- ja rahvaluuleteadlase Mihkel Veske leksikoloogiauuringuid Kaasani-perioodil (1886-1890), 
mil ta võrdlev-ajaloolisel meetodil uuris peamiselt läänemeresoome, vähem teiste soome-ugri keelte sõnakontakte algslaavi ja vene keelega ning vähesel määral ka balti keeltega. Asjakohane uurimus ilmus mahuka teosena autori surma-aastal (Veske 1890).

Siinkirjutaja analüüsib peale ajaloolise fooni loomise ja M. Veske monograafia kohta antud seniste hinnangute refereerimise Kaasani uurija teose esimest peatükki soome-ugri laenude kohta vene keeles ning üritab hinnata ta panust keeleteadusse õigete, poolenisti õigete ja valede etümoloogiate eristamise ja nende osatähtsuse kindlakstegemisega.

Kirjutises hinnatakse vene üldsõnade laenusuundade ja etümoloogiate õigsust tähendusrühmade kaupa Jalo Kalima uurimuse „Die ostseefinnischen Lehnwörter im Russischen” („Läänemeresoome laensõnad vene keeles", 1919), Max Vasmeri vene keele etümoloogilise sõnaraamatu (ESR) ja võimaluse korral ka hilisemate autorite tööde järgi. Kohanimed jäävad vaatluse alt välja. Läänemeresoome lekseemide omavahelist seost kontrollitakse vajaduse korral EES-i ja SSA põhjal. Seejuures ei pöörata tähelepanu läänemeresoome sõnade seostele kaugemate sugulaskeeltega. Siinkirjutaja on teadlik, et eri uurimused annavad kohati üsna erisuguseid tulemusi, kuid ta loodab, et käesoleval juhul ei ole lahknemised nii suured, et takistaksid protsentuaalsetest vahekordadest suhteliselt tõepärase pildi saamist.

Laensõnu käsitletakse käesolevas uurimuses enamasti ühtse skeemi järgi: vene laensõnale järgnevad selle esmakirjeldajate nimede lühendid ja sõna tähendused M. Veske järgi, seejärel tuuakse lühendi vrd järel soome sõna koos M. Veske esitatud tähendustega (tõlkes on siinkirjutaja neid lühendanud). M. Veske nime lühend lisatakse laensõna järele vaid juhul, kui ta on osutunud esmakirjeldajaks. J. Kalimal puuduvad laensõnad (nt laenud väljaspool läänemeresoome keeli, suisa valed etümoloogiad) on tähistatud tärniga *, v.a juhtudel, kui uurimuses ei kajastu terve sõnarühm. Selle järgi saab otsustada, kuivõrd soome uurija on aktsepteerinud M. Veske seisukohti.

Lühendit $v r d$ kasutatakse sellepärast, et vene sõna on tegelikult laenatud konkreetsest läänemeresoome keelekujust, enamasti kas karjala või vepsa keelest või mõnest tänaseks täiesti hääbunud keelekujust. Võrdlemisel kasutatakse ühtluse mõttes võimaluse korral siiski M. Veske kasutatud soome sõnu, kusjuures ruumi säästmiseks jäetakse keelelühend märkimata. Sõnatähenduste õigsuse kontrollimine ja võrdlemine tänastega 
võiks olla omaette uurimisteema. Praegusaegsete sõnastike kasutamine poleks siinkirjutaja meelest õigustatud, sest keel on rohkem kui sajandi vältel tunduvalt muutunud.

\section{Vene keelde laenatud soome-ugri sõnade uurimise ajaloost}

Soome-ugri laene on oletatud Loode-Venemaa vene keele murrakutes juba XVIII sajandi teisel poolel, aga võib-olla isegi varem. Näiteks arvas vene ajaloolane Nikolai Karamzin Holmogorõ linna nime tulenevat soome arvsõnast kolme (Veske 1890: 4-5). Järgnevalt tehakse Jalo Kalima (1919: 2-8) ja Sergei Mõznikovi (Myznikov 2003a: 44-45) tööde põhjal ülevaade laensõnade uurimise edasisest ajaloost. Arvestades M. Veske monograafia profiili, tulevad kõne alla üksnes läänemeresoome laenud.

Esimene nimeloend, mis sisaldab soome keelest laenatud sõnu vene keeles, on Venemaa Teaduste Akadeemia üllitises ilmunud laiade huvidega sõjaväe- ja riigitegelase Pjotr Butkovi mahukas artikkel „О финских словах в русском языке ..” (,Soome sõnadest vene keeles ..”, 1842). Soome vastet andmata eeldab autor õigesti paljude sõnade läänemeresoomelist päritolu, nt мерта 'mõrd', мянда 'mänd', сельга 'selg', соломя 'väin'.

Kaks aastat hiljem avaldas soome teadlane Matias Aleksanteri Castrén ajakirjas Suomi väikese artikli „Antekningar om Sawolotscheskaja Tschud” („Ülestähendusi Zavolotšje tšuudidest”, 1844) paarikümne PõhjaVenemaalt pärineva laensõnaga, millest umbes pooled olid õiged, sh лох 'lõhi', макса 'kalamaks', салма 'väin', шалга 'mets'.

Eelmainitutest tähelepanuväärsemaks peetakse akadeemik Andreas Johan Sjögreni teost „Материалы для сравнения областных великорусских слов со словами языков северных и восточных” („Materjale paikkondlike vene sõnade võrdlemiseks põhja- ja idakeeltega", 1854). ${ }^{1}$ See sisaldab peale läänemeresoome keelte võrdlusmaterjali ka teistest soome-ugri keeltest ja isegi kaugemalt. Õigesti määras uurija laenusuuna näiteks sõnadel веньгать 'vinguma', кехтать 'tahtma', кобра 'peotäis', малтать 'aru saama', seega J. Kalima andmeil taas umbes pooltel juhtudel. Kahjuks jõudis A. J. Sjögren varase surma tõttu laensõnu avaldada vaid $n$-täheni.

1 Keelte ja keelkondade nimetuste tõlgetes on arusaamatuste vältimiseks originaalide vananenud nimetused asendatud tänapäevastega. 
M. Veske monograafiat lugedes näib, et talle polnud asjaomased teosed (peale ühe M. A. Castréni teose) teada. Küll aga on ta maininud akadeemik Jakov Groti teose teist trükki pealkirja all „Слова областного словаря, сходные с финскими" ("Paikkondliku sõnastiku sõnad, mis sarnanevad soome sõnadega", 1876; I tr 1854; Veske 1890: 136). Teoses on peale uue ainese korratud peaaegu kõiki A. J. Sjögreni publitseeritud laensõnu. Nii neid kui ka uusi lekseeme mainis kümme aastat hiljem August Ahlqvist oma teoses „Kalevalan karjalaisuus” (,„Kalevala” karjalapärasus", 1887). Peale selle sisaldas läänemeresoome sõnalaene ka tšehhi keeleteadlase-slavisti Antonín Matzenaueri 1870. aastal ilmunud „Cizí slova ve slovanských řečéch” („Võõrad sõnad slaavi keeltes”). Nii A. J. Sjögren kui ka J. Grot on peale läänemeresoome laenude puudutanud ka idapoolsemate alade, sh Kaama ülemjooksu vene murretes leiduvat substraati (Gaidamaško 2013: 200).

Käsitletavat perioodi 1840.-1880. aastatel nimetab S. Mõznikov (Myznikov 2003a: 43) vene keeles leiduvate läänemeresoome laensõnade uurimise esimeseks etapiks, mil koguti keeleainest ja tehti esimesi katseid siduda vene sõnu läänemeresoome omadega.

Teine periood algas S. Mõznikovi sõnutsi M. Veskest ja lõppes J. Kalimaga. Sellal analüüsiti põhjalikult kogutud materjali, tehti ohtrasti konkreetseid järeldusi ja jõuti oluliste üldistusteni, mida kroonis Kalima „Die ostseefinnischen Lehnwörter im Russischen" 1919. aastal. Õigupoolest oli see 1915. aastal kaitstud magistritöö uustrükk, milles autor vaatles üle 500 laensõnapesa. Asjaomast teost peetakse musterteoseks laensõnade uurimise vallas (Myznikov 2003a: 48).

Teise perioodi suurepärased saavutused keelekontaktide uurimisel olid tingitud nii slaavi kui ka soome-ugri keelte leksikoloogia ja leksikograafia suhteliselt heast arengutasemest XIX sajandi lõpupoolel.

Toona ilmus mahukaid sõnaraamatuid üksikute soome-ugri keelte (eesti, soome, komi jt) kohta Ferdinand Johann Wiedemanni jt keelemeeste intensiivse töö tulemusel. Samuti oli käsikäes komparativistika arenguga hakatud avaldama võrdlevaid sõnaraamatuid. Nendeks olid ungari teadlase József Budenzi „Magyar-ugor összehasonlító szótár” („Soome-ugri võrdlev sõnaraamat”, 1873-1881) ning soome uurijate Otto Donneri ,Vergleichendes Wörterbuch der finnisch-ugrischen Sprachen 1-3” (,Soome-ugri keelte võrdlev sõnaraamat”, 1874-1888) ja August Ahlqvisti „Die Kulturwörter der westfinnischen Sprachen” („Läänemeresoome keelte 
kultuursõnad", 1875). Keele ja kultuuri suhete uurimisel sõnavara kaudu olid Soomes alates filoloogist ja ajaloolasest Henrik Gabriel Porthanist (1739-1804) juba pikaajalised traditsioonid (Herlin 2003: 116).

Ka M. Veske kasutas mainitud sõnaraamatuid oma uurimuses ning asus keele põhjal kultuurisuhteid vaatlema ilmselt just A. Ahlqvisti mõjul. Olulise impulsi sai ta ka taani teadlase Vilhelm Thomseni (1842-1927) dissertatsioonist germaani laensõnade kohta läänemeresoome ja saami keeltes. Selle töö tutvustamisega Õpetatud Eesti Seltsis algas M. Veske leksikoloogiaalane tegevus (Ernits 2010: 10). Pole ehk tähtsusetu mainida, et samal aastal M. Veske monograafiaga ilmus ka V. Thomseni läänemeresoome ja balti keelte vahelisi kontakte käsitlev tähtteos (Stieda 1990: 325).

Ka slavistika tegi XIX sajandi teisel poolel edusamme. Tugevnes vene keele leksikograafiline baas, sh Loode-Venemaa murdesõnavara vallas. Saaremaalt pärinenud slavisti Aleksandr Vostokovi (perekonnanimi õieti Osteneck) toimetusel ilmus „Опыт областного словаря великорусского языка” (,Vene keele paikkondliku sõnaraamatu katse”, 1852), Tartu ülikoolis end arstiks koolitanud Vladimir $\mathrm{Da}(\mathrm{h}) \mathrm{li}$ „Толковый словарь живого великорусского языка” („Elava vene keele seletussõnaraamat”, 1863-1866) ja kirjanik Aleksandr Podvõssotski „Словарь областного архангельского наречия” („Paikkondliku Arhangelski murde sõnastik”, 1885). Neid teoseid kasutas ka M. Veske, kusjuures pole võimatu, et Dali sõnaraamatu puhul selle teist trükki, mis ilmus aastatel 1880-1882 (Alvre 1993: 7, 8). XIX sajandi teise poole olulisimaid saavutusi slaavi keelte võrdlev-ajaloolise leksikoloogia vallas oli sloveeni keeleteadlase Fran(c) Miklošiči (saksapäraselt Franz Miklosich, 1813-1891) teos „Etymologisches Wörterbuch der slavischen Sprachen” (,Slaavi keelte etümoloogiline sõnaraamat", 1886), mida M. Veske ohtrasti kasutas slaavi algkeelest soome-ugri keeltesse siirdunud sõnade või hilisemate laenude uurimisel.

\section{M. Veske monograafiast ja selle senistest hinnangutest}

M. Veske põhjalik teos „Славяно-финские культурные отношения по данным языка” (,Slaavi ja soomeugri kultuurisuhted keeleandmete põhjal", 1890) ei sündinud Kaasani-perioodil paariaastase töö tulemusena, vaid see oli autori sõnutsi ideena saanud alguse juba üliõpilaspõlves Leipzigis kuulsate indoeuropeistide juures õppides ja nendega ligemalt 
lävides (Veske 1890: I; vt ka Ernits 2009: 56). Seejuures rõhutas M. Veske eriti professorite Friedrich Zarncke (1825-1891) ja August Leskieni (1840-1916) mõju. ${ }^{2}$ Muide, viimatimainitu töötas Leipzigi ülikoolis slaavi filoloogia professorina ning tegeles komparativistina balti ja slaavi keelte vallas. Tartu-perioodil ei saanud M. Veske keeleuurimisega materiaalsetel jm põhjustel intensiivselt tegelda. See õnnestus alles Kaasani-ajajärgul, mil tal jäi üle küllaldaselt aega, kuna ta jagas õpetust vaid ühele innukale kuulajale, professoriks valmistuvale Nikolai Tihhovile, ${ }^{3}$ kes luges oma õpetaja monograafia korrektuuri ja koostas raamatule registrid (Veske 1890: III).

Asjaomase monograafia põhiosa on esitatud veidi üle 300 leheküljel. Raamat koosneb kolmest osast: 1) soome-ugri sõnad vene keeles (lk 1-136), 2) algslaavi, vene ja balti sõnad soome-ugri keeltes (lk 137-260) ning 3) algslaavi, vene, balti ja soome-ugri keeltele ühised sõnad (lk 261-303). Teos oli kavandatud vähemalt kaheköitelisena, kusjuures viimane köide oleks sisaldanud lisanäiteid ning üldistusi keele ja kultuuri suhete kohta (Smirnov 1904: 56; vt ka Veske 1890: 260, 262, 303). Esimeses peatükis on erinevalt järgmistest vene laensõnad jagatud tähenduse järgi rühmadesse, milles neid on käsitletud tähestikjärjestusse paigutamata. Vene sõnale järgnevad näited teistest soome-ugri keeltest, kusjuures autor ei too enamasti selgelt esile, mis keelest või keelerühmast on sõna laenatud. Tagantjärele hinnates on tegemist enamasti laenuga läänemeresoome keeltest, mida $\mathrm{M}$. Veskel esindavad peamiselt eesti ja soome, harvem liivi keel. Vadja, isuri ja karjala keele näidete ärajätmise põhjuseks oli ilmselt vajalike sõnaraamatute puudumine. Volga keelte sõnavara on M. Veske ka ise kogunud ja monograafias kasutanud (Veske 1890: 125). Teose esimene osa sisaldab rohkesti kohanimesid.

Raamatu teises peatükis paigutas $M$. Veske esiplaanile sõnalaenude häälikulise vastavuse seaduspärasused, mis ta oli ise avastanud ja sõnastanud. Näiteks 20. seaduspärasuses räägib Veske, et soome-ugri $a$-le vastab laensõnades sageli vene ja vanaslaavi $o$, mille balti keelte vasteks on

2 Friedrich Zarncke tegeles peamiselt kirjandusteadusega.

3 M. Veske on monograafia eessõnas andnud Tihhovi nime ees initsiaalid N. Z, kuid M. Veske mälestuskogumikus (Dr. Mihkel Weske: 53) on ühes lookese tõlkes märgitud N. S., mida kasutas ka Johannes Kaup (1936: 42). Ilmselt on teisel juhul tegu ebatäpsusega. M. Veske õpilase näol on tegemist Nikolai Zahharovitš Tihhoviga, kes 1890. aastatel avaldas Kaasanis töid bulgaaria keelest ja kultuurist. 
taas $a$ (Veske 1890: 135, 177). Seaduspärasustele järgnevad keelenäited: kõigepealt F. Miklošiči rekonstrueeritud slaavi tüve algkuju, näited slaavi keeltest, vene sõnapesa, seejärel soome-ugri vasted. Monograafia kolmas osa on järjestatud jällegi vene sõnade järgi, mille laenusuund pole selge (seals: 261; vt ka Alvre 1993: 9-10).

M. Veske monograafiat on teadusavalikkus aegade vältel vastu võtnud mitmeti, enamasti küll positiivselt.

Omaaegne nõukogude fennougrist Dmitri Bubrich, kelle vaarisa oli Tartu ülikooli eesti keele lektor, pidas kõnesolevat monograafiat M. Veske põhiliseks teadussaavutuseks (tsit Myznikov 2003a: 46 järgi). Ent Soome tähtsaim slaavi ja balti laensõnade uurija Jalo Kalima väitis eesti teadlase kohta: „Autoril ei õnnestunud üldse selgeks teha ega välja joonistada tõepärast pilti läänemeresoome-slaavi ja läänemeresoome-balti kontaktidest ajaloolisel foonil." (Kalima 1952: 8). Paraku ei käsitle asjaomast Veske monograafiat Günter Johannes Stipa oma fennougristika ajaloo ülevaates (Stipa 1990).

Viimastel aastakümnetel on üritatud M. Veske uurimusele anda vääriline hinnang. Esimesena on M. Veske keelekontaktide monograafia põhjalikumalt vaatluse alla võtnud Paul Alvre (1993: 7-10). Ta nendib kokkuvõtteks: „Vaatamata mitmele puudusele (sealhulgas liigsele fantaasialennule, üldistuste nappusele ja kindla vahe puudumisele slaavi ja balti keelte vahel) tuleb $\mathrm{M}$. Veske mahukat ning faktitihedat uurimust slaavi ja soome-ugri kultuurisuhetest pidada oma aja kohta silmapaistvaks saavutuseks. Edasiseks keelekontaktide uurimiseks lõi see rikkaliku ja mitmekülgse ainesega tugeva põhja .." (seals: 10). Siinkohal võiks veel kord rõhutada, et üldistused oli M. Veske kavandanud teise köitesse.

Kõrgelt hindab M. Veske panust asjaomases valdkonnas tänapäeva olulisim läänemeresoome-vene keelekontaktide uurija, poolenisti vepsa juurtega Sergei Mõznikov. Kõigepealt on ta nentinud, et M. Veske oli üks väheseid uurijaid, kes tegeles ühtaegu nii läänemeresoome keeltest vene keelde laenatud sõnadega kui ka vene keelest läänemeresoome keeltesse siirdunud lekseemidega. M. Veske tegi kindlaks, et läänemeresoome keelte mõju vene keelele oli ulatuslik. Paljud (hinnangu andja ei täpsusta protsentides) tema antud etümoloogiad on osutunud õigeks. S. Mõznikov peab puuduseks asjaolu, et vene lekseeme oli kõrvutatud eesti ja soome andmetega, mitte aga karjala ja vepsa keele omadega (Myznikov 2003a: 45-46; EES). Teisal rõhutab S. Mõznikov, et M. Veske monograafia oli 
esimene teos, mis käsitles soome-ugri ja vene laenapellatiive kompleksselt. Seda põhjendab Peterburi uurija järgmiselt: 1) laensõnade uurimiseks oli olemas üsna lai andmebaas, 2) M. Veske paigutas apellatiivse materjali laia toponüümide konteksti, 3) vene murdesõnade uurimisel kasutas uurija peale soome-ugri keelte ka balti ja isegi turgi ainestikku (Myznikov 2004: 40-42).

\section{Kalanduse ja veesõiduga seotud laensõnad}

Enne konkreetsete laensõnade juurde asumist vaatles M. Veske monograafia esimese peatüki alguses soome-ugri sõnade laenamise põhjusi. Ta nentis, et enne koloniseerimist oli Põhja- ja Kesk-Venemaa asustatud üksnes soomeugrilastega. Põhja poole liikudes leidsid venelased eest teistmoodi looduse ja eluviisi ning olid sunnitud omandama põliselanikelt uusi sõnu endisel kodumaal tundmatute esemete ja nähtuste tähistamiseks. Koloniseerimise käigus muutusid soomeugrilased ajapikku kakskeelseks ja viimaks venekeelseks (Veske 1890: 1-2). See seisukoht väljendab selgesti kaua käibinud migratsiooniteooriat. Tänapäeval peetakse tõenäolisemaks keelevahetuse teooriat, mille kohaselt esikohal pole suure hulga uusasukate migreerumine, vaid prestiižikama keele piiride laienemine ja selle omandamine vallutatud alade põliselanike poolt (vt nt Ligi 1993: 109).

M. Veske jaotas oma teoses soome-ugri laensõnad neljaks rühmaks, mis on seotud 1) kalanduse ja veesõiduga, 2) loodusega, 3) esemete ja materjalidega ning 4) erisuguste mõistetega. Ta on uurinud 105 võimalikku soome-ugri laensõna (sõnapesa) vene keeles. Neist on seotud kalanduse ja veesõiduga 26 sõna(pesa) (24,8\%), mis tähistavad kalu ja muid meresaadusi, kalapüüki ja püügiriistu ning veesõidukeid ja nende osi.

Etümoloogiate õigsuse protsentuaalsel hindamisel jäävad välja sõnad, mis puuduvad ESR-is, ning sõnad, mille etümoloogia on tänini ebaselge. 26 laensõnast nelja õigsust ei saa kontrollida, sest lekseemid зельдь* 'Valge mere rääbis' jа лоншат* 'teatud arengujärgus lõhi' puuduvad M. Vasmeri sõnaraamatus ning sõna алажка алажна (V) 'paksu liivavõi mullakorraga kaetud koht laeva ninaosas, kus valmistatakse toitu' puhul pidas J. Kalima varasemat etümoloogiat õigeks, kuid M. Vasmer ei tunnistanud vene sõna läänemeresoome laenuks, ent ei pakkunud ka midagi selle asemele. Täiesti ebaselgeks on jäänud sõna селава* 'harilik viidikas’ algupära. Seega saab protsenti määrata 22 sõna kogumist. 
M. Veske on õigesti läänemeresoomeliseks tunnistanud 10 laensõna (45,5\%), sh емега ямега (V) 'nöör võrkude liitmiseks' (vrd jama 'võrguliitekoht') ${ }^{4}$, кирьяк (V) 'teatud arengujärgus lõhi', макса $(\mathrm{C}, \mathrm{Sj}$, A, D) 'lutsu niisk; valgevaala maks' (vrd maksa 'maks'), мерда морда (B, C, Sj) 'mõrd' (vrd merta 'väike mõrd'), лох (C, Sj) 'teatud arengujärgus lõhi' (vrd lohi 'lõhi'), салакуша (M) 'räim' (vrd salakka 'viidikas'), сельга * 'Valge mere rääbis' (vrd selkä 'selg'), соймa (C, Sj, A) 'ühemastiline purjelaev' (vrd saima $\sim$ soima 'suur lahtine või poolkinnine laev'), сорога (V) 'särg' (vrd särki 'särg'), торбать (V) 'mõrrapüügil aeruga kalu peletama' (vrd tarpoa 'jõel latiga paati tõugata; kalu võrku mütata'). Loendist selgub, et M. Veske ei olnud laensõna лох esimene etümologiseerija, nagu väitis S. Mõznikov (Myznikov 2003a: 166).

Osaliselt õigeks saab pidada üht laensõna (4,5\%), nimelt sõna вальчак (V) 'teatud arengujärgus lõhi'. M. Veske on lähtekeelt täpsemalt diferentseerimata esitanud võrdlusmaterjali nii läänemeresoome kui ka saami keeltest, kuid hiljem on omaks võetud üksnes saami algupära.

Ebaõige etümoloogia on selles rühmas kokku 11 sõnal (50\%). Sõna галадья галдья галлея (V) 'Valge mere idaheeringas' laenuallikaks on sm halle 'heeringas'. Soome-ugri laenudeks ei peeta sõnu мульга 'aeru või toetuslati käepide', мылиияа 'laeva kaldalt eemale tõukamise lati käepide', nан * 'teatud arengujärgus lõhi', селедеu* 'vinträim', селедка* 'heeringas' ја шалега* $\sim$ шелега* $\sim$ шелюга* $\sim$ шеляга* 'mereloomadelt saadav, sulatamata rasv'. Sõnad мульга ја мылица on vene keeles genuiinsed. Laensõna пан seostas M. Veske handi sõnaga, mis tähendab kalarikast jõemadalikku, kuid pärastpoole on lekseem usutavamalt ühendatud vene keelde laenatud poola sõnaga пан 'isand'. Шалега pole üle võetud soomeugrilastelt, vaid neenetsitelt.

M. Veske on ekslikult kõrvutanud eri lähtega lekseeme, nagu eespool nimetatud галадья галдья галлея (V) 'Valgemere idaheeringas (Clupea harengus pallasi n. maris-albi)' ning салакуша (M) 'läänemere (balti) heeringas ehk räim (Clupea harengus membras); balti kilu (Sprattus sprattus balticus)', селава* 'harilik viidikas (Alburnus alburnus)', селедеи* 'vinträim (Alosa fallax fallax)', селедка* 'harilik heeringas (Clupea harengus)' ja сельга* 'Valgemere rääbis (Coregonus sardinella maris-albi)', seega poolt tosinat omavahel kokkusobimatut kala-

${ }^{4}$ M. Veske toodud tähendus 'kammitsad, köidikud' on vist ebatäpne. 
nimetust. ${ }^{5}$ Uurija oli ebaõigel seisukohal, et käsitletud vene sal-, sel- ja gal-algulised kalanimetused on lähtunud läänemeresoome omadest. Tegelikult pärinevad nad eri tüvedest ja keeltest, nt галадья ja selle lähedased sõnad lähtuvad, nagu eespool mainitud, soome keelest, селедка aga Skandinaavia keeltest.

\section{Loodusega seotud laensõnad}

Looduse vallast on M. Veske analüüsinud 26 laensõna ehk 24,8\% laensõnade koguarvust. Lekseemid tähistavad maastikuelemente: veekogusid, metsa, aletatud kohta, kõrgustikku, järsakut ja kruusa; taimi: mändi, kasekäsna ja murakat; imetajaid: siga, hiirt; ning lindu.

Protsenti ei saa arvutada neljast sõnast: виселга* 'alumine latt lõhepüügivahendi vaiade külge kinnitatavast kolmest latist', жижка 'põrsas', mур *'ahi; ahjusamba jalg' jа чашельга* 'keskmine latt lõhepüügivahendi vaiade külge kinnitatavast kolmest latist', sest neist kolm puuduvad ESR-is. Vene murdesõna жижка on juba A. J. Sjögren ja küsimärgiliselt ka V. Dal kõrvutanud läänemeresoome lekseemiga sika. J. Kalima, kes jättis M. Veske mainimata, pidas seda kõrvutust karjala $\check{s}$ (sõnas šika) ja vene $\varkappa$ vastavuse sobimatuse tõttu ebakindlaks (Kalima 1919: 217). Vene keeles on teiste lõpuliite poolest sarnaste seanimetuste teke seotud nende sööma kutsumise hüüdega (vrd зюшка ја зю-зю, чушка ја чух-чух), kuid жижка puhul pole sobivat hüüet teada.

Järelejäänud 22 sõnast on M. Veske üldjoontes õigesti määranud 15 laensõna $(68,2 \%)$ päritolu: кенда $(\mathrm{Sj}, \mathrm{G})$ 'kõrge liivane järvekallas' (vrd kenttä 'kindel maapind, viljatu kõrge tasandik, muld, väli'), когма (Sj) 'pealmine lume- või jääkiht kevadel' (vrd kohva 'jääpank, -hunnik, -koorik'), конда = хонга ( $\mathrm{Sj}, \mathrm{G})$ 'kuivanud mänd, tavaliselt punakat värvust tugev mänd' (vrd honka 'vana mänd'), курья* 'pikk ja madal abajas; kuivanud jõesäng' (vrd komi куръя 'laht, jõekäär'), мороха* морошка* 'murakas' (vrd ee murakas), мянда мяндач $(\mathrm{Sj}, \mathrm{D} *, \mathrm{G})$ 'soomänd; palumänd' (vrd mänty 'mänd'), паккула (V) 'kasekäsn' (vrd pakkula samas tähenduses), caлма (B, C, G) 'väin; laht' (vrd salmi 'väin'),

\footnotetext{
${ }^{5}$ Aja jooksul on ladinakeelne terminoloogia oluliselt muutunud. Tänapäevaste ladina ja eesti nimetuste ning erikeelsete vastete kindlakstegemisel on kasutatud allikaid Lindberg, Gerd 1972, Mikelsaar 1984 ja Pihu 1979.
} 
чага* 'kasekäsn' (komi тшак 'seen'), шира 'hiir'* (vrd komi шыр samas tähenduses), moра (V) 'kruus' (vrd sora samas tähenduses), myn (V) 'tähendused samad mis sõnal zуza' (vrd suppu 'ummistav jäämass; peeneks raiutud õlg'), щелега 'üle veepinna ulatuv kivi' (vrd selkä 'selg, hari'), юркой (V) 'järsk; libe' (sm jyrkkä samas tähenduses), ягель (V) 'põdrasamblik' (vrd jäkälä 'samblik'). Muide, KESK peab sõna куръя laenusuunda ebaselgeks.

Sõna паккула päritolu pole hakatud uurima alles XX sajandi alguses, nagu kirjutas S. Mõznikov (Myznikov 2003a: 103), vaid sõna on käsitletud juba 1890. aastal. J. Kalima (1919: 244) polnud kindel, kas шалга (vt edaspidi) ja щзелега seostuvad omavahel, kuid S. Mõznikov (Myznikov 2003a: 308) peab viimase laensõna lähteks krj šelga't 'mäeselg'. Laensõna uирa, mille ka S. Mõznikov ühendas komi keelega, on talletatud kõigepealt XIX sajandi teisel kolmandikul Vologda kubermangu Jarenski maakonnast, mis ulatus Sõktõvkari külje alla ja oli asustatud osaliselt komidega, osaliselt venelastega; sama aastasaja teisel poolel pandi sõna kirja ka Jaroslavli kubermangust (Myznikov 2004: 31, 299; Jarenskij uezd). Juhul, kui asjaomane laensõna pole naabruses paiknevasse Jaroslavli kubermangu kandunud siirdlastega, siis tuleb nõustuda käesoleva kirjutise esimese retsensendi arvamusega, et seal võib olla tegemist vepsa-merja substraatlaenuga, kusjuures vene $u$ on tekkinud esimese palatalisatsiooni tulemusena.

Poolenisti õigesti on M. Veske kindlaks teinud kolme laensõna (13\%) päritolu: кулига (B) 'aletatud maatükk; muudest struktuuridest ümbritsetud maastikuelement; järsk jõekallas', шалга (C, A) 'niiske paik, kus kasvab kõrge kuusik ja kanarbik; põõsaid täis kasvanud metsaala, kus raiutakse küttepuid; laialdane metsaala, mille keskel leidub järvi' (vrd selko 'kauge mets') ja щуза myz myx (V) 'jões ujuv esimene sügisjää koos lumepankadega; kevadine õhuke jääkirme või -supp'.

Laensõna кулига arvas J. Kalima tulenevat läänemeresoome sõnast külä 'küla', mida M. Vasmer ei pidanud küllaldaseks kogu sõnapesa päritolu seletamisel. S. Mõznikovi arvates võiks sõna üheks läänemeresoomeliseks lätteks olla M. Veske pakutud kolkka 'kolgas' (Myznikov 2003a: 241). Sõna шалга käsitelu on M. Veskel pikk ja sõnaseoste leidmise poolest kohati üsna keeruline. Uurija on ebaõigesti paigutanud O. Donneri soome-ugri keelte võrdleva sõnaraamatu põhjal ühte etümoloogilisse ritta sm sõnad salo 'metsane saar; suur põlismets', selko selkä 'selg; mäeselg, 
-hari', selkeä 'selge' ja ee sõna salk (lisaks veel salmi 'väin'). Tegelikult on salo balti laen ja salk võib sellest tuleneda, kuid selkeä on iseseisev sõna ning ainult selko tuleneb sõnast selkä.

Laensõna $m y z a \sim m y z \sim m y x$ 'jões ujuv esimene sügisjää koos lumepankadega; kevadine õhuke jääkirme või -supp' puhul on uurija õigesti määranud laenusuuna, kuid esitanud vasteks sobimatud ee soga ja sm soka 'ropsmed'. J. Kalima (1919: 248) pakutud sm sohja sohjo 'lörts; jääsoga' sobib küll häälikuliselt paremini, kuid mitte laitmatult.

Vale laenuallikaga on tegu ainult nelja laensõna $(18,2 \%)$ puhul. Колдоб ${ }^{*}$ 'veega täidetud auk' ja луток* 'pardi või sukelpardi liik' on vene keeles genuiinsed. Komi keelest on üle võetud мег (V) 'jõekääru vette ulatuv kaldaosa'. Läänemeresoome keeltest pärineb шалга (V) 'ülemine latt lõhepüügivahendi vaiade külge kinnitatavast kolmest latist', mida ei saa erinevalt M. Veske väitest seostada sõnaga шалга metsa tähenduses (vt eespool), vaid tegu on eraldi laensõnaga (vrd salko 'latt; teivas'). Viimase lekseemi puhul jätab J. Kalima (1919: 245) M. Veske ei mainimata.

\section{Esemete ja materjalidega seotud laensõnad}

M. Veske on oma monograafias käsitlenud 15 esemete ja materjalidega seotud laensõna (14,2\%). Tegu on suhteliselt väikese sõnarühmaga, millesse on koondatud nahast ja puust esemed, sh jalatsid, puunõud. Selle rühma laensõnade seas pole aga kalapüügivahendite ega nende osade nimetusi, mis on paigutatud mujale, v.a тарья 'kalatõkke rest'.

ESR-is puuduvad кyma* 'hütt; ait' (M. Veske on muide võrdlusainest esitanud volga keeltest) ja шабала * 'lagunenud rõivas või nõu; haavapakk puunõude tegemiseks'. M. Vasmer pidas murdelekseemi елаха* 'õlu; praska' päritolu ebaselgeks, pooldades ise küll pigem selle ühendamist vene genuiinse sõnaga $о л$ 'alkohoolne jook, v.a viinamarjavein'. Seetõttu saab protsenti arvutada vaid 12 sõnast.

Üldjoontes on M. Veske selles rühmas õigesti seletanud kuus sõna (50\%): гигна игна хигна $(\mathrm{Sj})$ 'põhjapõdrarakendi ohjad' (vrd hihna 'rihm'), кен(b)га (B, M) 'saabaste peale asetatav jalavari; vildist või nahast talvejalats; sooja voodriga, säärteta nahkjalats' (vrd kenkä 'king'), койбa (Sj, D) 'põhjapõdra jalgadelt nülitud, töödeldud nahk' (vrd koipa 'koib'), курика (V) 'puidust puulõhkumisvahend' (vrd kurikka 'kurikas; kaigas'), 
paxa (G, D) 'raha' ja сарья (V) 'kepikestest villavanutamisvahend' (vrd sarja 'rida; harjake; trepp') ${ }^{6}$.

Päris õige tulemuseni pole $M$. Veske jõudnud kahe sõna $(16,7 \%)$ puhul: лянгас* 'suur torbik' (vrd mr längõ š 'puunõu; suur tünn, milles pruut toob näha oma kaasavara') ja ляник (D) 'suur puuvaagen' (vrd ee länik). Paraku pole M. Veske kummagi laensõna puhul lähtekeelt eraldi näidanud. EES ja SSA ei kõrvuta viimast sõna mari vastega ilmselt erineva sõnasisese konsonantismi tõttu.

Ebaõigesti on M. Veske seletanud nelja sõna (33,3\%): кан(ь)ги каньи 'ülespoole painutatud ninadega saami jalatsid', сарга (V) 'laastud, vitsad või männi- ja seedrijuured sidumiseks ja punumiseks; niin', тарья (V) 'kalatõkkerest' ja шакала* шаколина* 'tatraterade kestad'. Juba J. Kalima (1919: 112) mainis, et M. Veske ei lahutanud läänemeresoome keeltest pärinevat sõna кен(b)гa ja saami keeltest üle võetud sõnu кан(b)гu $\sim$ каньи 'liik saami jalavarje'. Seevastu capra pole vene keelde siirdunud mari, vaid mõnest läänemeresoome keelest (vrd sarka 'tohuriba; põlluvõi metsariba'). M. Veske oletas läänemeresoome ja mordva vastavuse $s \sim t$ põhjal ebaõigesti ka тарья puhul lekseemide sarja ja tarja (samuti sarka) omavahelist seotust, teadmata neist eraldi seisva soome-ugri sõna olemasolust (vrd sm tarja 'laastudest punutud reepõhi või raam; laast-, kõrkja- või õlgmatt'; EES: sõna tari all). M. Veske ühendas шакала jt ebaõigesti soome-ugri sõnadega, sh lõunaeesti murdesõnadega sõkla 'sõklad' ja sõgel 'sõel'. Tegelikult pole need omavahel suguluses, sest esimene on laenatud läti, teine aga alggermaani keelest; käsitletavat vene sõna peetakse otselaenuks balti keeltest (ESR). Seega oli M. Veske õigele laenuallikale üsna lähedal.

\section{Tähenduselt rühmitamata laensõnad}

Viimaks asutagu M. Veske sõnutsi ,tähenduselt rühmitamatute sõnade” käsitlemisele. Neid on arvult 38 ehk 36,2\%. Verbid moodustavad analüüsitavast rühmast enamiku (32 ehk 84,2\%), ülejäänud sõnad kuuluvad substantiivide hulka.

Protsendiarvestusest jääb välja 10 sõna, millest M. Vasmeri sõnaraamatus puuduvad кауриться 'kulmu kortsutama; altkulmu vaatama',

6 EES: 461 ei anna tähendusi 'harjake' ja 'trepp', kuid on lisanud tähendused 'raam', 'liist' ja 'ääris'. 
кетовать 'andma midagi käega', котылиить котычить 'kõditama', куердить 'üles kloppima; keerutama; sassi ajama', paбить 'tagaajamismängus neiut püüdma' ja тякчить 'peeneks raiuma'; ülejäänute etümoloogiat pole uuritud või see on jäänud ebaselgeks: галубать ( $\mathrm{Sj}$ ) 'kõvasti tahtma', ковырять 'uuristama, koukima', колготать 'vaidlema; irisema', кувыркать 'kukerpallitama'. Neist sõnadest on галубать ( $\mathrm{Sj}$ ) 'kõvasti tahtma' ainuke, mille esitab oma loendis J. Kalima, pidades seda häälikulistel põhjustel küsimärgiliselt läänemeresoome sõnaks (vrd haluta 'tahta, soovida'). Tähenduse poolest on kahtlane kõrvutada sõnu колготать ja kolkottaa 'koputada; kellegi peale karjuda'. Рабить on M. Veske arvates vähemalt läänemeresoomeline (vrd rapaistaa 'kinni haarata'), kuid sõna тякчить puhul on ta toonud võrdluseks üksnes ee täksima. Mõlemad kõrvutused võiksid põhimõtteliselt olla õiged. Verbi кувьлккать etümoloogia on ebaselge, kuid kindlasti pole ta soome-ugri laen. Seega jääb protsentarvutuseks 28 sõna.

M. Veske on käsitletavas rühmas õigesti määranud 12 laensõna (42,9\%): венгать вянгать $(\mathrm{Sj})$ 'nuttes kaeblema; ebaselgelt või kaeblevalt rääkima' (vrd vinkua 'vinguda; oiata; uluda'), кехmams (Gr, Sj) 'soovima; ülemäära sööma, pintslisse panema; raskustega töötama' (vrd kehdata 'julgeda; viitsida' $)^{7}$, кобарка кобра (Gr, Sj) 'peotäis' (vrd koura $<* k$ корra 'peotäis; kamalutäis'), колкать (Sj) 'uksele või väravale koputama' (vrd kolgata 'koputada, kloppida'), кульпаться*'vees rabelema', ленгузить * льнгузить * 'laisklema; töölt pagema' (ka tegijanimena ленгас ленчуг ленгась льнгуз), ляпать * 'paugutama; patsutama; lapiti lööma; midagi kleepuvat märga pilduma' (vrd läpyttää 'plaksutada; matsutada'), малтать (Sj) 'aru saama, taipama' (vrd malttaa 'aru saada, taibata; ennast tagasi hoida; suuta'), равга (Gr) 'nääre; paise' (ee Võru rauh nääre), mурба (V) 'koon (näo osa)', mypmams * 'tülitama' (vrd komi turtõdny 'painama, tü̈̈tama'), шагла шегла шогла щзагла* щзегла* (V?) 'palk, -gi; varras' (vrd salko 'pikk latt'; vt Kalima 1919: 245 шалга all).

Sõna kульпаться $(\mathrm{Sj})$ 'vees rabelema' pidas $\mathrm{M}$. Vasmer pigem genuiinseks, väites, et sm kylpeä laenamisel pidanuks vene keeles hääliku $p$ asemel peaks olema $b$. Ent pole võimatu, et $p$ võis tekkida tähenduselt mõneti lähedase sõna купаться 'suplema' mõjul. Tegusõna ленгузить льнгузить ja sellega seonduvad tegijanimed on arvatud õigete hulka, sest hoolimata M. Vasmeri seletusest, et nad on vene päritolu, ühtib siinkirjutaja

7 Juba J. Kalima märkis õigusega, et tähenduse 'sööma' teke jääb mõistatuseks. 
EES-i arvamusega (P. Ariste järgi), mille kohaselt lõngus on eesti keelest laenatud vene keelde.

Ebaõigeks on osutunud $16 \mathrm{M}$. Veske oletatud laensõna seletust (57,1\%; kõik puuduvad ka J. Kalima loendis). Neist on vene keeles genuiinsed ботать 'põtkima', вехоть вихоть 'heina- või õletuust; räbal', гоumb 'hoolitsema; söötma', коверзень 'viisud', коверкать 'painutama, murdma; mudima', лебезить 'lipitsema; keelt peksma', льндать 'töölt pagema; ümber hulkuma; laisklema', льımams (samad tähendused mis eelmisel), мулить 'hõõruma; valusalt pigistama; loiult mäluma või rääkima; tüütama', ряхаться 'venitama, koperdama', торкать торнуть 'tõukama; sakutama; koputama, kolkima', mурить турять 'ära ajama; kiirustama', холить 'koristama; hoolitsema', юрить 'rahmeldama; kiirustama'. Seevastu vene кульма 'võrgupära või kitsam koht' pärineb komi keelest, vrd kulem kulõm 'lõks; võrk' (ESR II: 409-410); teisalt pole välistatud ka asjaomase sõna genuiinsus (Myznikov 2003b: 181). Verbi кайковать * 'nukrutsema; ebalema; kahetsema' lähteks pidas M. Veske ee sõna kõigutama, sm sõnu kaikottaa 'karjuma panna' ja kaikua 'heliseda' ning ersa sõna kajgoms 'helisema', mis aga ei sobi tähenduse poolest, ning vene lekseemi on J. Kalima hiljem ühendanud sm sõnaga kaikkoa 'kurvastada' (ESR). Läänemeresoome levikuga torkama-sõna on uurijad pidanud kas vene laenuks või ekspressiivsõnaks.

On võimalik, et esitatud vene murdesõnadest osutub detailsemal uurimisel veel mõnigi praegu genuiinseks peetav soomeugriliseks või vastupidi. Näiteks холить 'koristama; hoolitsema', mida M. Vasmer pidas üsna sarnaste slaavi vastete pärast genuiinseks, on tähenduselt siiski ka väga lähedane asjaomastele läänemeresoome sõnadele, vrd sm huolittaa 'muretseda neiu mehelemineku pärast; ehtida; koristada; hoolikalt valmistada'.

Hakkab silma, et viie eespool mainitud laenverbi (рабить, тякчить, венгать, колкать, ленгузить) läänemeresoome lähted kuuluvad ekspressiiv- ehk deskriptiivleksika hulka (EES-is ,häälikuliselt ajendatud”); ilmselt selliseid tüvesid laenataksegi nende väljendusrikkuse tõttu hõlpsamalt. Edaspidi vajaks uurimist, kas ekspressiivsõnu märkas esimesena M. Veske või olid need juba varem tuntud. Nimelt nentis uurija, et läänemeresoome sõnad, mille koostises on kas 1) $k+$ lühike vokaal + ver, 2) $k+$ pikk vokaal $+r$ või 3) $k+$ diftong $+r$ tähistavad 'välja või sisse õõnestatud, kõver, kääruline', vrd kõver, keerama (Veske 1890: 118). Neile vastab sageli ka vene keeles sama koosseis, kuid uurijatel pole õnnestunud leida seost läänemeresoome ja vene (slaavi) sõnade vahel. 


\section{Kokkuvõtteks}

M. Veske on käsitlenud ühtekokku 105 vene murdesõna, mis tema väitel on laenatud soome-ugri keeltest. Neist on ta 21 sõna ehk viiendikku uurinud esimesena. Osa asjaomastest laensõnadest ei kajastu enam hilisemates uurimustes, osa päritolu on aga tänini lõplikult selgitamata. Selliseid sõnu on ligemale $20 \%$. Uurija jättis monograafias enamasti täpsemalt lähtekeele või keelerühma märkimata, kuid sõnakuju ja tähenduse järgi tagantjärele otsustades on neist enamik pärit läänemeresoome keelerühmast. Muudest soome-ugri keeltest on õige etümoloogiaga laensõnade hulgas vaid neli komi päritolu vene lekseemi: курья, туртать, иира ја чага.

M. Veske etümologiseeritud kalanduse ja veesõiduga seotud laensõnadest osutusid õigeks ainult pooled. Suur osakaal valesid etümoloogiaid on tingitud sellest, et uurija ühendas omavahel pool tosinat sal-, sel- ja gal-algulisi kalanimetusi, mis aga tegelikult on erinevat algupära. Kõige õigemini on M. Veske seletanud loodusega seotud laensõnu, mille hulgas leidub tänini käibivaid etümoloogiaid $68 \%$.

Esemete ja materjalidega seotud laensõnadest on õigesti etümologiseeritud jällegi ainult pooled. Tegu on suhteliselt väikese rühmaga, mistõttu see ei ole eriti tõestusvõimeline. Peaaegu kolmandiku uuritud sõnadest jättis M. Veske tähenduse järgi rühmitamata. Kui eelmised rühmad koosnevad nimisõnadest (tegusõnadest vaid mopбать), siis neljandasse rühma on koondatud suuremalt jaolt verbid (nimisõnu vaid 20\% ringis). Selles rühmas on õigesti määratud kõigest $43 \%$ laensõnadest. Nii läänemeresoome kui ka vene (slaavi) sõnade seas leidub rohkesti ekspressiivleksikat, mis komplitseerib genuiinsuse või laenulisuse määramist.

Kokkuvõtlikult võib nentida, et M. Veske on oma monograafias õigesti etümologiseerinud ligemale 52\% enda käsitletud laensõnadest; lisaks on umbes $9 \%$ osaliselt õigeid etümoloogiaid. Kahjuks pole võrdlusmaterjali teiste XIX sajandi uurijate tulemuslikkuse kohta, ent tahaks loota, et seda tulevikus lisandub. M. Veske teost ei saa võrrelda vene keele läänemeresoome laenude uurimise teise perioodi lõppu tähistava J. Kalima monograafiaga, sest vahepeal oli keeleteadus jõudsate sammudega edasi arenenud. M. Veske panus soome-ugri keeltest vene keelde laenatud sõnade uurimisse on kahtlemata tuntav, liiati kui erinevalt eelkäijatest pole tegu pelga sõnaloendiga, vaid esimese argumenteeritud teemakohase teadustööga. 


\section{Läänemeresoome laensõnu käsitlenud uurijate nimede lühendid ja asjaomaste teoste ilmumisaasta}
A - A. Ahlqvist (1887), B - P. Butkov (1842), C - M. A. Castrén (1844),
D - V. Dal (1863-1866), Gr - J. Grot (1854), M - A. Matzenauer (1870),
$\mathrm{Sj}-$ A. J. Sjögren (1854), V - M. Veske (1890)

\section{Kirjandus}

Alvre, Paul 1993. Mihkel Veske fennougristina. - Keel ja Kirjandus 1, 1-10.

Dr. Mihkel Weske = Dr. Mihkel Weske 25. surmapäeva mälestuseks. 1915. Jurjew: Eesti Kirjandus.

EES = Eesti etümoloogia sõnaraamat. 2012. Koost. ja toim. Iris Metsmägi, Meeli Sedrik, Sven-Erik Soosaar. Peatoim. Iris Metsmägi. Tallinn: Eesti Keele Sihtasutus.

Ernits, Enn 2008. Läänemeresoome käändesüsteemidest Mihkel Veske kirjatööde valgusel. - Emakeele Seltsi aastaraamat 53 (2007). Peatoim. Mati Erelt. Tallinn: Teaduste Akadeemia Kirjastus, 23-37.

Ernits, Enn 2009. Mihkel Veske uurimustest soome-ugri keelte morfoloogia vallas. - Emakeele Seltsi aastaraamat 54 (2008). Peatoim. Mati Erelt. Tallinn: Teaduste Akadeemia Kirjastus, 54-71.

Ernits, Enn 2010. Mihkel Veske uurimustest eesti keele leksikoloogia vallas. Emakeele Seltsi aastaraamat 55 (2009). Peatoim. Mati Erelt. Tallinn: Teaduste Akadeemia Kirjastus, 9-31.

ESR = Макс Фасмер 1986-1987. Этимологический словарь русского языка. 1-4. Издание второе, стереотипное. Москва: Прогресс.

Gaidamaško, Roman 2013. Finno-Ugric substrate apellatives in Russian dialects of the Upper Kama. - Areal Linguistics, Grammar and Contacts. (=Eesti ja soome-ugri keeleteaduse ajakiri 4-2.) Tartu, 199-216.

Herlin, Ilona 2003. Sanat ja asjat. - Virittäjä 1, 116-123.

Jarenskij uezd = Яренский уезд. http://ru.wikipedia.org/wiki (20.02.2014).

Kalima, Jalo 1919. Die ostseefinnischen Lehnwörter im Russischen (= Suomalais-ugrilaisen Seuran toimituksia 44.) Helsinki: Société Finno-Ougrienne.

Kalima, Jalo 1952. Slaavilaisperäinen sanastomme. Tutkimus itämerensuomalaisten kielten slaavilaisperäisistä lainasanoista. (= Suomalaisen Kirjallisuuden Seuran toimituksia 243.) Helsinki: Suomalaisen Kirjallisuuden Seura.

Kaup, Johannes 1936. Dr. Mihkel Veske. Keeleteaduse pioneer ja isamaalsuse raudne tulehoidja. (= Eesti rahvuslikud suurmehed. Elulooline kirjastik noorsoole, III sari, nr 16.) Tallinn: Kooli-Kooperatiiv. 
KESK = Василий И. Лыткин, Евгений С. Гуляев 1970. Краткий этимологический словарь коми языка. Институт языкознания Академии наук СССР, Коми филиал АН СССР. Москва: Наука.

Ligi, P[eeter] 1993. Vadjapärased kalmed Kirde-Eestis (9.-16. sajand). - Muinasaja teadus 2. Vadjapärased kalmed Eestis 9.-16. sajandil. Toim. Valter Lang. (= Töid arheoloogia alalt 1.) Tallinn, 7-175.

Lindberg, Gerd 1972 = Георгий У. Линдберг, Александр С. Герд. Словарь названий пресноводных рыб СССР на языках народов СССР и европейских стран [около 9000 наименований]. Ленинград: Наука.

Mikelsaar, N[eeme] 1984. Eesti NSV kalad. Käsiraamat-määraja. Tallinn: Valgus.

Myznikov 2003a = Сергей А. Мызников. Русские говоры Обонежья. Ареально-этимологическое исследование лексики прибалтийскофинского происхождения. Российская академия наук, Институт лингвистических исследований. Санкт-Петербург: Наука.

Myznikov 2003b = Сергей А. Мызников. Атлас субстратной и заимствованной лексики русских говоров Севера-Запада. Российская академия наук, Институт лингвистических исследований. Санкт-Петербург: Наука.

Myznikov 2004 = Сергей А. Мызников. Лексика финно-угорского происхождения в русских говорах Севера-Запада. Этимологический и лингвогеографический анализ. Российская академия наук, Институт лингвистических исследований. Санкт-Петербург: Наука.

Pihu 1979 = Loomade elu. 4, Kalad. Toim. Ervin Pihu. Tallinn: Valgus.

Smirnov $1904=$ И. Н. Смирнов. Веске, Михаил Петрович. - Биографический словарь профессоров и преподавателей Императорского Казанского университета. За сто лет (1804-1904). 1, Кафедра православного богословия, факультеты историко-филологический (с разрядом восточной словесности и лектурами) и физико-математический. Под редакцией Николай П. Загоскина. Казань, 54-60.

SSA = Suomen sanojen alguperä. Etymologinen sanakirja. 1-3, 1992-2000. Päätoim. Erkki Itkonen, Ulla-Maija Kulonen. (= Suomalaisen Kirjallisuuden Seuran toimituksia 556, Kotimaisten kielten tutkimuskeskuksen julkaisuja 62.) Helsinki: Suomalaisen Kirjallisuuden Seura, Kotimaisten kielten tutkimuskeskus.

Stipa, Günter Johannes 1990. Finnisch-ugrische Sprachforschung. Von der Renaissance bis zum Neupositivismus. Redaktionelle Bearbeitung und Zusammenstellung der Bibliographie Klaas Ph. Ruppel. (= Suomalaisugrilaisen Seuran toimituksia 206.) Helsinki: Suomalais-ugrilainen Seura.

Veske 1890 = Михкель П. Веске. Славяно-финские культурные отношения по данным языка. (= Известия Общества Археологии, Истории и Этнографии при Императорском Казанском университете 8, 1.) Казань. 


\title{
Concerning the contribution of Mihkel Veske to the investigation of Finno-Ugric loanwords in Russian
}

\author{
Enn Ernits
}

The paper provides an analysis of the first chapter of the monograph of the Estonian linguist Mihkel Veske (earlier Michael Weske; 1843-1890) concerning words in Russian dialects borrowed from Finno-Ugric languages (Veske 1890). First, a short overview is given of the monograph and previous evaluations of it, as well as the history of the 19th-century investigation of these loanwords. In the main part of the paper an attempt has been made to evaluate the contribution of $\mathrm{M}$. Veske to the investigation of loanwords by differentiating and calculating the percentage of correct, nearly correct and incorrect etymologies.

$\mathrm{M}$. Veske has investigated 105 Finno-Ugrian loanwords in Russian, including 21 words that have not previously been studied. The most Russian words have been borrowed from the Finnic languages. Only four loanwords derive from the Komi language: курья 'long, shallow creek; dried river bed', туртать 'disturb', иира 'mouse', and yага 'tinder fungus (Inonotus obliquus)'.

The paper analyzes the correctness of Veske's etymologies and assumed directions of borrowing, dividing the words examined into different groups based on their meaning. Half of the etymologies of the loanwords connected with fishing and water transport, as well as those related to products and materials, were correct. M. Veske has most successfully analyzed loanwords connected with nature: $70 \%$ of them were correct. The group of unclassified words contains $43 \%$ correct etymologies. The majority of words in this group are verbs. In summary, one can assert that $\mathrm{M}$. Veske correctly etymologized $50 \%$ of the loanwords he investigated.

Undoubtedly, M. Veske has significantly contributed to the investigation of Finno-Ugric loanwords in Russian. Moreover, unlike the works of his forerunners, his monograph is not only a word list, but the first argued research on the topic.

Keywords: Mihkel Veske, history of linguistics, Finnic languages, lexicology, language contacts, comparative method

\section{Enn Ernits}

veterinaaria alusteaduste ja populatsioonimeditsiini osakond

Eesti Maaülikool

Kreutzwaldi 62

51014 Tartu

enn.ernits@emu.ee 